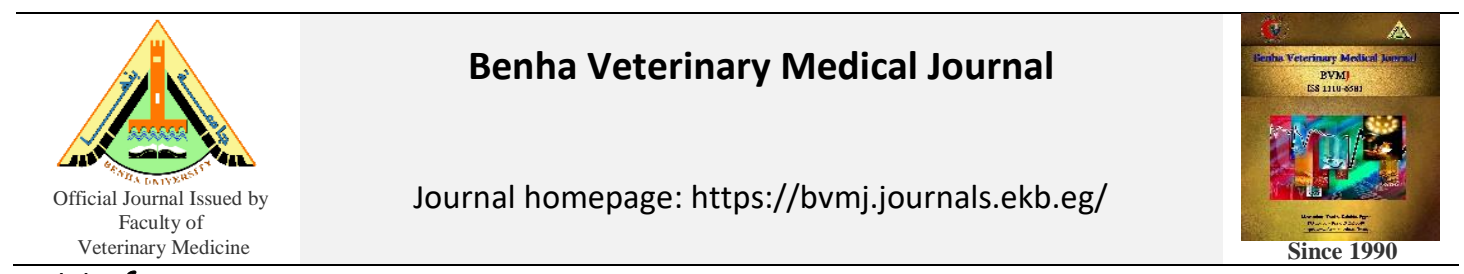

Original Paper

\title{
Some organic acids as antifungal on frozen duck meat
}

\author{
Amani M. Salem ${ }^{1}$, Marionette Z. Nassif ${ }^{2}$, Amira M. Abd-Elhalim ${ }^{2}$ \\ ${ }^{1}$ Food Hygiene Department., Fac. of Veterinary Medicine, Benha University, Egypt \\ ${ }^{2}$ AnimalHealth Research Institute (Benha branch), Egypt
}

\begin{tabular}{|c|c|}
\hline ARTICLE INFO & ABSTRACT \\
\hline $\begin{array}{l}\text { Keywords } \\
\text { Antifungal } \\
\text { Duck meat } \\
\text { Fungi } \\
\text { Mold } \\
\text { Organic acids } \\
\text { Received 06/10/2019 } \\
\text { Accepted 04/11/2019 } \\
\text { Available On-Line } \\
\text { 12/05/2020 }\end{array}$ & $\begin{array}{l}\text { This study was conducted to evaluate the antifungal effect of some organic acid on frozen duck } \\
\text { meat. The used organic acids for decontamination of frozen duck meat (breast and thigh) } \\
\text { samples were acetic and citric acids in concentrations of }(2 \%, 5 \%) \text { and combination of both } \\
(2 \%) \text { by soaking. Acetic acid }(2 \% \text { and } 5 \%) \text { decreased yeast and mold count (cfu/g) from } \\
5.7 \times 10^{2} \pm 0.17 \times 10^{2} \text { (initial load) to } 1.1 \times 10^{2} \pm 0.05 \times 10^{2} \text { and } 0.46 \times 10^{2} \pm 0.03 \times 10^{2} \text { with a } \\
\text { reduction percentage } 80.7 \% \text { and } 91.9 \% \text { in breast samples, and from } 6.8 \times 10^{2} \pm 0.2 \times 10^{2} \text { (initial } \\
\text { load) to } 2.6 \times 10^{2} \pm 0.15 \times 10^{2} \text { and } 1,1 \times 10^{2} \pm 0.12 \times 10^{2} \text { with a reduction percentage } 61.7 \% \text { and } \\
83.8 \% \text { for thigh samples, respectively. Citric acid }(2 \% \text { and } 5 \%) \text { decreased yeast and mold count } \\
\text { (cfu/g) from } 5.7 \times 10^{2} \pm 0.17 \times 10^{2} \text { (initial load) to } 1.4 \times 10^{2} \pm 0.18 \times 10^{2} \text { and } 0.56 \times 10^{2} \pm 0.03 \times 10^{2} \\
\text { with a reduction percentage } 75.4 \% \text { and } 90.1 \% \text { for breast samples, respectively, and from } \\
6.8 \times 10^{2} \pm 0.2 \times 10^{2} \text { (initial load) to } 3.4 \times 10^{2} \pm 0.14 \times 10^{2} \text { and } 1.3 \times 10^{2} \pm 0.08 \times 10^{2} \text { with a reduction } \\
\text { percentage } 50 \% \text { and } 80.8 \% \text { for thigh samples, respectively. While, combination of both acids } \\
(2 \%) \text { decreased the count with a reduction percentage } 75.4 \% \& 90.1 \% \text { in breast and } 50 \% \text { \& } \\
80.8 \% \text { in thigh ones. Acetic acid }(5 \%) \text { had the highest antifungal effect, therefore, it is } \\
\text { recommended to improve safety of duck meat. }\end{array}$ \\
\hline
\end{tabular}

\section{INTRODUCTION}

Duck meat is considered a good source of high biological value proteins for humans (Adzitey et al., 2012a) and is rich in iron, selenium, and niacin, as well as containing fewer calories than many cuts of beef (Adzitey et al., 2012b). Duck and geese production accounts for about $7.5 \%$ of the total world poultry meat production (Pigel, 2004).

Mold and yeast comprise a large group of microorganisms which are ubiquitous in nature due to easy dissemination and their vegetative spores, which are produced in large numbers and can present in the environment for a long period. Contamination of duck meat with mold starts in the environment of the slaughter halls due to a lack of hygienic measures through air, wall, floor, utensils, feather and intestinal contents of the slaughtered birds (Mansour, 1986). Contaminated feed is a main source for mold infection and mycotoxin in farm animal (Sayed et al., 2000). The incidence of meat contamination with different mold genera was investigated in different localities of the world such as Australia, Japan, Italy and Spain (Iacumin, et al., 2009; Martín-Sánchez, et al., 2011).

Fungi are not only major spoilage agents of meat results in reduction of quality with significant economic losses but also cause contamination of most food substance with secondary metabolites called mycotoxins (Adeyeye 2016). The ingestion of such mycotoxins has enormous public health significance, because these toxins are capable of causing diseases in man and animals ranging from death to chronic interference with the function of the nervous, cardiovascular, pulmonary and endocrine systems as well as alimentary tract (John and Miller, 2017)

Human exposure to aflatoxins is primarily from a consumption of contaminated food directly like cereals, seeds, fruits, etc., or indirectly by eating food products and by-products obtained from animals consuming contaminated feeds (Galvano et al., 2005).

Organic acids generally recognized as safe agents for the preservation of foods, inhibition of growth by weak acid preservatives has been proposed to be due to a number of actions including, membrane disruption, inhibition of essential metabolic reactions, stress on intracellular $\mathrm{pH}$ homeostasis and the accumulation of toxic anions. In yeasts, it has also been proposed that the actual inhibitory action of weak acid preservatives could be due to the induction of an energetically expensive stress response that attempts to restore homeostasis, and results in the reduction of available energy pools for growth and other essential metabolic functions (Bracey et al., 1998; Stratford and Anslow, 1998; Dalie et al., 2010).

Citric acid a white powder extracted from the juice of citrus and other acidic fruits such as lemons, limes, pineapples and gooseberries. It is also produced by the fermentation of glucose. Citric acid is highly soluble in water and primarily insoluble in fat. Citric acid was investigated for its effect on inhibition of bacteria, yeast and molds (Sorrells, 1989).

Acetic acid is commonly known as vinegar which has antimicrobial capabilities due to its ability to lower the $\mathrm{pH}$

\footnotetext{
* Corresponding author: Amira M. Abd-Elhalim. Animal Health Research Institute (Benha branch), Egypt
} 
and cause instability of bacterial cell membranes (Jay, 1992).

Therefore, the target of this work was to assess the antifungal effect of acetic and citric acids in frozen duck meat.

\section{MATERIAL AND METHODS}

\subsection{Collection of samples:}

Samples of frozen duck meat (breast and thigh (200 gm of each) were collected from different localities in El-Qalyubia governorate markets, Egypt. Samples were identified, packed and transferred to the laboratory in icebox under complete aseptic conditions without undue delay and were subjected to the mycological examination.

\subsection{Organic acids used:}

Acetic acid glacial 99-100\% a.r. (Chem-Lab NV, Batch No. 25.5952809 ) that was prepared with sterile distilled water to reach $(2 \& 5 \%)$. Citric acid anhydrous oral (El Gomhouria Co, Batch No. 2AZ1704047) that was prepared with sterile distilled water to reach $(2 \& 5 \%)$.

\subsection{Experimental application:}

Frozen duck meat (breast and thigh) samples were thawed in chilling temperature and divided into untreated (control) and treated groups with acetic and citric acids in concentrations of $(2 \%, 5 \%)$ and combination of both $(2 \%)$ by dipping for 15 min. All groups were mycologically examined. The experiment was conducted in triplicate.

\subsection{Preparation of samples (APHA, 2001)}

After thawing, $25 \mathrm{gm}$ of examined duck meat samples were aseptically excised and homogenized in $225 \mathrm{ml}$ of sterile buffered peptone water $0.1 \%$ at $2000 \mathrm{rpm}$ for $1-2 \mathrm{~min}$ using a sterile homogenizer. Such homogenate represents the dilution of $10^{-1}$, and then decimal dilutions were done. Then the prepared samples were subjected to:

1) Mold and yeast count (Bailey and scott, 1998)

2) Isolation and identification of isolated mold and yeast based on their micromorphological properties (Pitt and Hocking 2009) .

\section{RESULTS}

It is evident from the result recorded in table (1) that the mean value of yeast and mold counts (cfu/g) in the examined frozen breast groups were $5.7 \times 10^{2} \pm$ $0.17 \times 10^{2}, 1.1 \times 10^{2} \pm 0.05 \times 10^{2}$, with a reduction percentage $80.7 \%, 0.46 \times 10^{2} \pm 0.03 \times 10^{2}$, with a reduction percentage $91.9 \%, 1.4 \times 10^{2} \pm 0.18 \times 10^{2}$, with a reduction percentage $75.4 \%, 0.56 \times 10^{2} \pm 0.03 \times 10^{2}$, with a reduction percentage $90.1 \%$, and $1.2 \times 10^{2} \pm 0.11 \times 10^{2}$, with a reduction percentage $78.9 \%$ incontrol and treated with acetic acid (2\%), acetic acid (5\%), citric acid (2\%), citric acid $(5 \%)$ and a combination of both acids (2\%) groups, respectively. There was a significant difference between untreated breast samples and treated ones. Moreover, the mean value of yeast and mold counts (cfu/g) in the examined frozen thigh groups were $6.8 \times 10^{2} \pm 0.20 \times 10^{2}$ in control samples, while, $2.6 \times 10^{2} \pm 0.15 \times 10^{2}$ with a reduction percentage $61.7 \%$ in acetic acid $(2 \%), 1.1 \times 10^{2} \pm 0.12 \times 10^{2}$ with a reduction percentage $83.8 \%$ in acetic acid $(5 \%), 3.4 \times 10^{2} \pm 0.14 \times 10^{2}$ with a reduction percentage $50 \%$ in citric acid $(2 \%)$, $1.3 \times 10^{2} \pm 0.08 \times 10^{2}$ with a reduction percentage $80.8 \%$ in citric acid $(5 \%)$ and $1.3 \times 10^{2} \pm 0.13 \times 10^{2}$ with a reduction percentage $80.8 \%$ in combination of both acids $(2 \%)$. There was a significant difference between untreated thigh samples and treated ones.

Table 1 Effect of organic acids on mold and yeast count in frozen duck meat samples.

\begin{tabular}{|c|c|c|c|c|}
\hline $\begin{array}{l}\text { Duck samples } \\
\text { treated with organic } \\
\text { acids }\end{array}$ & Minimum & Maximum & Mean \pm S.E.* & $\begin{array}{c}\text { Red. } \\
\%\end{array}$ \\
\hline \multicolumn{5}{|l|}{ Breast samples } \\
\hline Control & $5.4 \times 10^{2}$ & $6 \times 10^{2}$ & $5.7 \times 10^{2} \pm 0.17 \times 10^{2 b}$ & - \\
\hline Acetic acid (2\%) & $1 \times 10^{2}$ & $1.2 \times 10^{2}$ & $1.1 \times 10^{2} \pm 0.05 \times 10^{2 \mathrm{e}}$ & 80.7 \\
\hline Acetic $\operatorname{acid}(5 \%)$ & $4 \times 10$ & $5 \times 10$ & $0.46 \times 10^{2} \pm 0.03 \times 10^{2 \mathrm{f}}$ & 91.9 \\
\hline Citric $\operatorname{acid}(2 \%)$ & $1.1 \times 10^{2}$ & $1.7 \times 10^{2}$ & $1.4 \times 10^{2} \pm 0.18 \times 10^{2 \mathrm{e}}$ & 75.4 \\
\hline Citric acid (5\%) & $5 \times 10$ & $6 \times 10$ & $0.56 \times 10^{2} \pm 0.03 \times 10^{2 f}$ & 90.1 \\
\hline Acetic+ Citric(2\%) & $1 \times 10^{2}$ & $1.4 \times 10^{2}$ & $1.2 \times 10^{2} \pm 0.11 \times 10^{2 \mathrm{e}}$ & 78.9 \\
\hline \multicolumn{5}{|l|}{ Thigh samples } \\
\hline Control & $6.5 \times 10^{2}$ & $7.2 \times 10^{2}$ & $6.8 \times 10^{2} \pm 0.20 \times 10^{2 a}$ & - \\
\hline Acetic acid ( $2 \%)$ & $2.3 \times 10^{2}$ & $2.8 \times 10^{2}$ & $2.6 \times 10^{2} \pm 0.15 \times 10^{2 \mathrm{~d}}$ & 61.7 .8 \\
\hline Acetic acid(5\%) & $1 \times 10^{2}$ & $1.4 \times 10^{2}$ & $1.1 \times 10^{2} \pm 0.12 \times 10^{2 \mathrm{e}}$ & 83.8 \\
\hline Citric acid(2\%) & $3.2 \times 10^{2}$ & $3.7 \times 10^{2}$ & $3.4 \times 10^{2} \pm 0.14 \times 10^{2 \mathrm{c}}$ & 50 \\
\hline Citric acid (5\%) & $1.2 \times 10^{2}$ & $1.5 \times 10^{2}$ & $1.3 \times 10^{2} \pm 0.08 \times 10^{2 \mathrm{e}}$ & 80.8 \\
\hline Acetic+ Citric $(2 \%)$ & $1.2 \times 10^{2}$ & $1.6 \times 10^{2}$ & $1.3 \times 10^{2} \pm 0.13 \times 10^{2 \mathrm{e}}$ & 80.8 \\
\hline
\end{tabular}

It is evident from the result recorded in table (2) that breast samples are free from A. fumigatus. while, the mean values of A. fumigatus (cfu/g) in the examined frozen thigh groupwere $4.6 \times 10 \pm 0.3 \times 10,2.3 \times 10 \pm 0.3 \times 10$, with a reduction percent $50 \%, 3.3 \times 10 \pm 0.3 \times 10$, with a reduction percent $28.2 \%$ and $3 \times 10 \pm 0.0 \times 10$, with a reduction percent $34.7 \%$ in control and treated with acetic acid (2\%), citric acid (2\%) and citric acid (5\%), respectively. Furthermore, acetic acid $(5 \%)$ and acetic and citric acid combination (2\%) inhibited the growth of A. fumigatus (Red\% $=100)$.

Also, the result in table (2) revealed that the mean values of A. flavus $(\mathrm{cfu} / \mathrm{g})$ in the examined frozen breast \& thigh groups were $4.6 \times 10 \pm 0.6 \times 10 \& 6.3 \times 10 \pm 0.3 \times 10$ in control samples, while they were $1.3 \times 10 \pm 0.3 \times 10 \& 3.3 \times 10 \pm 0.3 \times 10$ with a reduction percent $71.7 \%$ \& 47.6 , in acetic acid $(2 \%)$, $0 \& 1.6 \times 10 \pm 0.3 \times 10$, with a reduction percent $100 \% \&$ $74.6 \%$, in acetic acid (5\%), $2 \times 10 \pm 0.5 \times 10 \& 4.6 \times 10 \pm 0.3 \times 10$, with a reduction percent $56.5 \% \& 26.9 \%$, in citric acid $(2 \%)$, $1 \times 10 \pm 0.0 \times 10 \& 3 \times 10 \pm 0.0 \times 10$, with a reduction percent $78.2 \% \& 52.3 \%$ in citric acid $(5 \%)$ and $0,2.6 \times 10 \pm 0.3 \times 10$ with a reduction percent $100 \% \& 58.7 \%$, in acid combination $(2 \%)$, respectively.

Moreover, the result in table (2) revealed that the mean values of $A$. niger $(\mathrm{cfu} / \mathrm{g})$ in the examined frozen breast $\&$ thigh groups were $26.3 \times 10 \pm 0.8 \times 10 \& 57.6 \times 10 \pm 0.3 \times 10$ while, they were $6.3 \times 10 \pm 0.3 \times 10 \& 21.6 \times 10 \pm 0.3 \times 10$, with a reduction percent $76 \%$ \& $62.5 \%, 2 \times 10 \pm 0.5 \times 10$ \& $2 \times 10 \pm 0.0 \times 10$, with a reduction percent $92.3 \% \& 96.5 \%$, $6.6 \times 10 \pm 0.8 \times 10 \& 29.6 \times 10 \pm 0.3 \times 10$, with a reduction percent $74.9 \%$ \& $48.6 \%, 3.3 \times 10 \pm 0.3 \times 10 \& 4.6 \times 10 \pm 0.3 \times 10$, with a reduction percent $87.4 \% \& 92 \%$ and $4.3 \times 10 \pm 0.3 \times 10 \&$ $8.6 \times 10 \pm 0.3 \times 10$, with a reduction percent $83.6 \%$ \& $85 \%$ in control and treated with acetic acid (2\%), acetic acid (5\%), citric acid $(2 \%)$ and citric acid $(5 \%)$ and a combination of both acids, respectively. Also, the result in table (2) revealed that the mean values of Rhizopus (cfu/g) in the examined frozen breast\& thigh groups were $23.6 \times 10 \pm 0.8 \times 10$ \& $7.6 \times 10 \pm 0.3 \times 10$ in control samples, while they were $4.3 \times 10 \pm 0.3 \times 10 \& 1.3 \times 10 \pm 0.3 \times 10$, with a reduction percent 
$81.7 \%$ \& $82.8 \%$, in acetic acid $(2 \%), 1.6 \times 10 \pm 0.3 \times 10 \& 0$, with a reduction percent $93.2 \% \& 100 \%$, in acetic acid (5\%), $3.6 \times 10 \pm 0.3 \times 10 \& 2 \times 10 \pm 0.0 \times 10$, with a reduction percent $84.7 \%$ \& $73.6 \%$, in citric acid (2\%), $1.6 \times 10 \pm 0.8 \times 10 \& 0$, with a reduction percent $93.2 \%$ \& $100 \%$ in citric acid (5\%)and $2.6 \times 10 \pm 0.8 \times 10 \& 1 \times 10 \pm 0.0 \times 10$, with a reduction percent $88.9 \%$ \& $86.8 \%$ in combination of both acids $(2 \%)$ groups, respectively.

\begin{tabular}{|c|c|c|c|c|c|c|c|c|}
\hline \multirow{2}{*}{$\begin{array}{l}\text { Duck samples treated } \\
\text { with organic acids }\end{array}$} & \multirow{2}{*}{$\begin{array}{l}\text { Aspergillus flavus } \\
\text { Mean } \pm \text { S.E.* }\end{array}$} & \multirow[b]{2}{*}{$\operatorname{Red} \%$} & \multicolumn{2}{|c|}{ Aspergillus fumigatus } & \multicolumn{2}{|l|}{ Aspergillus niger } & \multicolumn{2}{|l|}{ Rhizopus } \\
\hline & & & Mean \pm S.E.* & Red\% & Mean \pm S.E.* & $\operatorname{Red} \%$ & Mean \pm S.E.* & Red. \% \\
\hline \multicolumn{9}{|l|}{ Breast samples } \\
\hline Control & $4.6 \times 10 \pm 0.6 \times 10^{b}$ & _- & _- & _- & $26.3 \times 10 \pm 0.8 \times 10^{c}$ & _- & $23.6 \times 10 \pm 0.8 \times 10^{\mathrm{a}}$ & _- \\
\hline Acetic acid $(2 \%)$ & $1.3 \times 10 \pm 0.3 \times 10^{\mathrm{f}}$ & 71.7 & - & _ & $6.3 \times 10 \pm 0.3 \times 10^{f}$ & 76 & $4.3 \times 10 \pm 0.3 \times 10^{c}$ & 81.7 \\
\hline Acetic $\operatorname{acid}(5 \%)$ & _ & 100 & - & _ & $2 \times 10 \pm 0.5 \times 10^{\mathrm{h}}$ & 92.3 & $1.6 \times 10 \pm 0.3 \times 10^{\mathrm{ef}}$ & 93.2 \\
\hline Citric $\operatorname{acid}(2 \%)$ & $2 \times 10 \pm 0.5 \times 10^{\text {def }}$ & 56.5 & _ & _ & $6.6 \times 10 \pm 0.8 \times 10^{\mathrm{f}}$ & 74.9 & $3.6 \times 10 \pm 0.3 \times 10^{\mathrm{cd}}$ & 84.7 \\
\hline Citric acid (5\%) & $1 \times 10 \pm 0.0 \times 10^{\mathrm{f}}$ & 78.2 & _ & _ & $3.3 \times 10 \pm 0.3 \times 10^{\mathrm{gh}}$ & 87.4 & $1.6 \times 10 \pm 0.8 \times 10^{\mathrm{ef}}$ & 93.2 \\
\hline Acetic+ Citric $(2 \%)$ & - & 100 & - & - & $4.3 \times 10 \pm 0.3 \times 10^{g}$ & 83.6 & $2.6 \times 10 \pm 0.8 \times 10^{\mathrm{de}}$ & 88.9 \\
\hline \multicolumn{9}{|l|}{ Thigh samples } \\
\hline Control & $6.3 \times 10 \pm 0.3 \times 10^{\mathrm{a}}$ & _- & $4.6 \times 10 \pm 0.3 \times 10^{\mathrm{a}}$ & _ & $57.6 \times 10 \pm 0.3 \times 10^{\mathrm{a}}$ & _- & $7.6 \times 10 \pm 0.3 \times 10^{\mathrm{b}}$ & _- \\
\hline Acetic acid (2\%) & $3.3 \times 10 \pm 0.3 \times 10^{\mathrm{c}}$ & 47.6 & $2.3 \times 10 \pm 0.3 \times 10^{\mathrm{c}}$ & 50 & $21.6 \times 10 \pm 0.3 \times 10^{\mathrm{d}}$ & 62.5 & $1.3 \times 10 \pm 0.3 \times 10^{\mathrm{f}}$ & 82.8 \\
\hline Acetic $\operatorname{acid}(5 \%)$ & $1.6 \times 10 \pm 0.3 \times 10^{\mathrm{f}}$ & 74.6 & - & 100 & $2 \times 10 \pm 0.0 \times 10^{\mathrm{h}}$ & 96.5 & _- & 100 \\
\hline Citric $\operatorname{acid}(2 \%)$ & $4.6 \times 10 \pm 0.3 \times 10^{\mathrm{b}}$ & 26.9 & $3.3 \times 10 \pm 0.3 \times 10^{b}$ & 28.2 & $29.6 \times 10 \pm 0.3 \times 10^{\mathrm{b}}$ & 48.6 & $2 \times 10 \pm 0.0 \times 10^{\mathrm{ef}}$ & 73.6 \\
\hline Citric acid (5\%) & $3 \times 10 \pm 0.0 \times 10^{\mathrm{cd}}$ & 52.3 & $3 \times 10 \pm 0.0 \times 10^{\mathrm{b}}$ & 34.7 & $4.6 \times 10 \pm 0.3 \times 10^{g}$ & 92 & - & 100 \\
\hline Acetic+ Citric $(2 \%)$ & $2.6 \times 10 \pm 0.3 \times 10^{\mathrm{cde}}$ & 58.7 & _ & 100 & $8.6 \times 10 \pm 0.3 \times 10^{\mathrm{e}}$ & 85 & $1 \times 10 \pm 0.0 \times 10^{f}$ & 86.8 \\
\hline
\end{tabular}

\section{DISCUSSION}

Mold contamination of duck meat starts in the environment of the slaughter halls due to a lack of hygienic measures through air, wall, floor, utensils, feather, operators' hands and intestinal contents of the slaughtered birds (Mansour, 1986). Hence, the prevention of mold to gain access the meat is absolutely necessary. Acetic acid and citric acid are antimicrobial agents approved by USDA (FDA, 2003).

Result in table (1) revealed that yeast and mold counts of frozen duck in both breast and thigh groups were lowered by treatment with organic acids by dipping for 15 minutes in different reduction $\%$. The effect of organic acids is mainly assigned to its ability to penetrate the cell membrane in its dissociated form, wherein more of the acid would be undissociated at lower $\mathrm{pH}$ than at neutral (Lin, et al. 2005) and enter the cytoplasm of the cell, dissociate within the cell and therefore decreasing the intracellular $\mathrm{pH}$, providing acid-binding capacity (Roth and Kirchgessner, 1995), increasing the turgor pressure within the cell due to increase in anions from the acids and expulsion of $\mathrm{H}^{+}$ions from the cell (Foster, 1999), disturbing transmembrane proton motive force, denaturating acid-sensitive proteins and DNA (Davidson, 2001) and causing an inhibition of acid sensitive enzyme (Davidson and Tylor,2007) and various essential metabolic and anabolic processes (Abee and Wouters, 1999). These actions weaken the cell. Consequently, acetic acid treated samples were the highest antifungal group than others. It interferes with cytoplasmic membrane structure and membrane proteins such that electron transport is uncoupled, and subsequent ATP production is reduced (Davidson, 2001). Moreover, as shown in tables (2) results illustrated that, acetic acid (5\%) had complete and partial inhibition in growth of both of A. flavus, A. fumigatous, $A$. niger \& Rhizopus in different reduction levels in both breast and thigh samples than other treatments.

Our results agree with Maehashi et al. (1996), who mentioned that acetic acid inhibits both bacteria and molds. Dorsa et al. (1997) (citric, lactic and aceti (organic acids rinses) as a single or in combination have been shown to be effective in reducing both spoilage and pathogenic microorganisms). In addition, Dubal, et al. (2003) found that spoilage organisms were highly sensitive to acid combination treatment as compared to lactic acid alone; Mohamed, et al. (2008) (reported that the four organic acids approaches (citric, lactic, acetic and tartaric) were presented as fresh beef shelf life extenders), the shelf-life of acid and acid combination treated samples was increased to 8 and 11 days as against 3 days in untreated samples. Pelaez, et al. (2012) determined that the increase of acid in the medium decreases the growth rate and extends the lag phase and Irkin, et al. (2015) who found that $2 \%$ acetic acid washing solutions showed significant inhibitory effects against yeast and molds $(\mathrm{P}<0.05)$ as they were reduced from 5.70 \pm 0.08 to $4.38 \pm 1.00$ ( $\log \mathrm{cfu} / \mathrm{g} \pm$ standard deviation).

Regarding the effect of organic acids on Aspergillus gerera, our results in table (2) agree with Hassan et al. (2015), who found that acetic acid $(10 \%)$ has the highest inhibitory effect on A. flavus being $45.21 \%$, but acetic acid (5\%) has $(27.92 \%)$ inhibition \% and citric acid $(5 \%)$ gave lowest inhibition effect $(0.42 \%)$. In addition, Dalie et al. (2010) who reported that, acetic acid was more effective than lactic acid and was the best inhibitor for fungi growth, El- shemy et al. (2016), who said that antimicrobial activity of acetic acid is higher than citric acid and Pundir and Jain (2010) acetic acid showed maximum antifungal activity against two isolates each of Aspergillus. luchuensis, A. flavus, Rhizopus. stolonifer, Mucorsp. (100\%). But disagree with Sorrells (1989), who mentioned that citric acid was shown to be inhibitor than lactic acid and acetic acid.

Regarding to the effect of the used acids on Rhizobus, our results agree with Hassan, et al. (2015), who found that inhibition $\%$ of $5 \%$ acetic acid and $5 \%$ citric acid on Rhizopus. Nigricans was nearly the same $(17.27 \%$ and $18.03 \%$ respectively). 


\section{CONCULOSION}

It can be concluded that the use of acetic and citric acids potential decontaminants and acetic acid (5\%) proved to be more efficient antifungal one. Therefore, recommended to improve quality and safety of duck meat.

\section{REFERENCES}

1. (APHA) American puplic health association 2001.Compendium of methods for microbiological examination of foods. $4^{\text {th }}$ Ed. F. P. Downes and K. ito (editors), APHA. Washington D. C., USA.

2. Abee, T., Wouters, J.A. 1999. Microbial stress response in minimal processing. Int. J. Food Microbiol., 50: 65-91.

3. Adeyeye, S.A.O. 2016. Fungal mycotoxins in foods: A review. Cogent Food Agric., 2: 1213127

4. Adzitey, F., Rusul, G., Huda, N. 2012a. Prevalence and antibiotic resistance of Salmonella serovars in ducks, duck rearing and processing environments in Penang, Malaysia. Food Res. Int. 45(2): 947-952.

5. Adzitey, F., Huda, N., Rusul, G. 2012b. Prevalence and antibiotic resistance of Campylobacter, Salmonella, and L. monocytogenes in ducks: A Review. Foodborne Pathog. Dis. 9, 498-505.

6. Bailey, W.R, Scott, E.G. 1998. Diagnostic microbiology textbook for isolation and identification of pathogenic organisms. The C.V Mosby Company Sarnt Houis.

7. Bracey, D., Holyoak, C.D., Coote, P.J. 1998. Comparison of the inhibitory effect of sorbic acid and amphotericin B on Saccharomycescerevisiae: is growth inhibition dependent on 1997). reduced intracellular $\mathrm{pH}$ ? J. Appl. Microbiol. 85(6): 1056-66

8. Dalie, D.K.D. Deschamps, A.M., Forget, F.R. 2010. Lactic acid bacteria-potential for control of mold growth and mycotoxins: A review, Food Control, Vol. 21, pp 370-380.

9. Davidson, P.M. 2001. Chap. 29. Chemical preservatives and natural antimicrobial compounds. PP. 593-627 in Food Microbiology-Fundamentals and Frontiers. $2^{\text {nd }}$ Ed. American Society for Microbiology, Washington, DC.

10. Davison, P.M., Taylor, T.M. 2007. Chemical preservatives and natural antimicrobial compounds. In: Doyle, M.P. and L.R Beichat, (E.ds.), Food Microbiology: Fundamentals and forontiers.ASM Press, Washington DC, pp: 713-745.

11. Dorsa, W.J., Cutter, C.N., Iragusa, G.R. 1997. Bacterial profile of ground beef made from carcass tissue experimentally contaminated with pathogenic and spoilage bacteria before being washed with hot water, alkaline solution, or organic acids and then stored at 4 or $12^{\circ} \mathrm{C}$. J. Food Prot., 6: 1109-1118.

12. Dubal, B.Z., Paturkar, M.A., Waskar, S.V., Zende, J.R., Latha, C., Rawool, B.D., Kadam, C. 2003. Effect of food grade acids on inoculated $S$. aureus, L. monocytogenes, $E$. coli and $S$. Typhimuriumin sheep/goat meat stored at refrigerated temperature. J. Meat Sci., 51: 142-147.

13. El- shemy, M.G.Y., Nessrien M.N. Yasin., Gadallah, M.G.E. and Eman K.N. Hanafi (2016): Microbiological Quality and Enzymes Activity of Refrigerated Bolti Fish (Tilapia nilotica) Pretreated with Organic Acids. J.A.V.S., 9(1): 57-70

14. FDA. 2003. Code of Federal Regulations Title 21, Government Printing Office, USA
15. Foster, J.W. 1999. When protons attack: microbial strategies of acid adaptation. Curr. Opin. Microbiol., 2:170-174.

16. Galvano, F., Ritieni, A., Piva, G., Pietri, A. 2005.Mycotoxin in the human food chain. In: The Mycotoxins Blue Book. (D. Diaz, ed) pp 187-224.Nottingham Uni. Press, Nottingham, UK.

17. Hassan, R., El-Kadi, S. and Sand, M. 2015. Effect of some organic acids on some fungal growth and their toxins production. IJAB., 2 (1)

18. Iacumin, L., Chiesa, L., Boscolo, D., Manzano, M., Cantoni, C., Orlic, S., Comi, G. 2009.Moulds and ochratoxin A on surfaces of artisanal and industrial dry sausages. Food Microbiol., 26: 65-70

19. Irkin, R., Degirmencioglu, N., Guldas, M. 2015. Effects of organic acids to prolong the shelf-life and improve the microbial quality of fresh cut broccoli florets. Qual. Assur. Saf. Crop., 7 (5): 737 - 745

20. Jay, J.M. 1992. Intrinsic and Extrinsic Parameters of Food that Affect Microbial Growth. In: Modern Food Microbiology, Jay, J.M. (Ed.). vi Book, New York, pp: 38-62.

21. John, I.P., Miller, J.D. 2017. A conscise history of mycotoxin research. J. Agric. Food Chem., 65:7021-7033.

22. Lin, Y.T., Labbe, R.G., Shetty. K. 2005. Inhibition of V. parahaemolyticus in seafood systems using lactic acid. Innovative Food Science and Emerging Technologies, 6: 453 458.

23. Maehashi, K., Yamamoto, Y., Higashi, K., Yoshii, H. 1996. Effects of acetic acid on respiration of Debaryomyceshansenii. Nippon Shokuhin Kagaku Kogaku Kaishi 43: 225-230.

24. Mansour, N.K.M. 1986. Zum Vorkommen von Schimmelpilzen der Gattung Cladosporium link Ex Fries auf Schaffleisch. Ph. D Thesis, Munchen, Germany.

25. Martín-Sánchez, A.M., Chaves-López, C., Sendra, E., Sayas, E., Fenández-López, J., Pérez-Álvarez, J.A. 2011. Lipolysis, proteolysis and sensory characteristics of a Spanish fermented dry-cured meat product (salchichón) with oregano essential oil used as surface mold inhibitor. Meat Sci., 89: 35-44.

26. Pelaez, A.M.L., Catano, C.A.S., Yepes, E.A.Q., Villarroel, R.R.G., Antoni, G.L.D., Giannuzzi, L. 2012. Inhibitory activity of lactic and acetic acid on Aspergillus flavus growth for food preservation. Food Control, Vol. 24, pp 177-183.

27. Pingel, H. 2004. Duck and geese production around the world poultry magazine. $8(20)$ : $26-28$

28. Pitt, J. I., Hocking, A.D. 2009. Fungi and Food spoilage. 3rd Ed. Springer Science + Business Media, LLC, 233 Spring Street, New York, NY 10013, USA

29. Pundir, R.K., Jain, P 2010.Screening for antifungal activity of commercially available chemical food preservatives. Int. J. Pharm. Sci. Rev. Res., 5 (2):25-27

30. Roth, F.X., Kirchgessner, M. 1995. The role of formic acid in animal nutrition. BASF AG Ludwigshafen, Fifth Forum Animal Nutrition, pp:5-20.

31. Sayed, M.A., Mohamoud, E.L.A., Abou-EIAlIa, A.A 2000."Mycoflora and natural occurrence of mycotoxins in meat and livers of imported bulls, poultry and some meat products, Assuit Vet. Med. J., 43: 188-200.

32. Sorrells, K.M. 1989. Effect of $\mathrm{pH}$ acidulant, time and temperature on the growth of Listeria monocytogenes. J. Food Prot., 52: 571-573.

33. Stratford, M., Anslow, P.A. 1998. Evidence that sorbic acid does not inhibit yeast as a classic "weak acid" preservative. Lett. Appl. Microbiol. 27: 203-206. 